\title{
PENGARUH PRICE EARNING RATIO (PER), PRICE BOOK VALUE (PBV) DAN DEBT TO EQUITY RATIO (DER) TERHADAP RETURN SAHAM \\ (Studi terhadap Perusahaan Properti dan Real Estate yang Listing di Indeks Saham Syariah Indonesia) ${ }^{11}$
}

\author{
Rendra Akbar \\ Mahasiswa Program Studi S1 Ekonomi Islam-Fakultas Ekonomi dan Bisnis-Universitas Airlangga \\ Email: akbarrendra@gmail.com
}

Sri Herianingrum

Departemen Ekonomi Syariah-Fakultas Ekonomi dan Bisnis-Universitas Airlangga

Email: sriheria@yahoo.co.id

\begin{abstract}
:
Every investor wants a secure investment and provides profit (in-return). This study aimed to analyze the effect of Price Earnings Ratio (PER), Price Book Value (PBV) and Debt to Equity Ratio (DER) on stock returns Vendor property and real estate listed in Indonesian Sharia Stock Index (ISSI) in the period 2011-2013. This study used quantitative analysis with panel data estimation methods with time series in 2011-2013 and cross section data of thirty-one companies used $a=5 \%$ significance level. The regression results in this study indicated that the independent variables Price Earnings Ratio (PER) and variable Debt to Equity Ratio (DER) significantly shown negative effect on stock returns, meanwhile the variable Price Book Valve (PBV) significantly shown positive effect on stock returns. While simultaneously brought a significant effect on stock returns and real estate properties listed in Indonesian Sharia Stock Index (ISSI) in period 2011-2013.
\end{abstract}

Keywords: Price Earnings Ratio, Price Book Value, Debt to Equity Ratio, Return Stocks and Shares Index Sharia Indonesia

\section{PENDAHULUAN}

Investasi tidak lagi menjadi lain dan merupakan bentuk aktif dari sesuatu yang asing di telinga kita dan bukan merupakan kegiatan baru di dalam dunia perekonomian Indonesia. Dengan didukung oleh keterbukaan informasi yang ada, masyarakat dapat dengan mudah mengenal investasi melalui surat kabar, televisi, radio dan informasi yang disampaikan oleh teman maupun keluarga.

Investasi merupakan salah satu kegiatan muamalah yang sangat dianjurkan karena dengan berinvestasi, harta yang menjadi lebih produktif dan juga mendatangkan manfaat bagi orang ekonomi syariah. Islam menganjurkan agar sumber daya yang ada tidak hanya disimpan, tetapi diprodukifkan sehingga bisa memberikan manfaat bagi umat ( Hidayat, $2011: 24$ ).

Sesuai dengan perintah Allah kepada kita untuk tidak melupakan kebahagiaan kita di dunia di dalam QS, Al - Qasas ayat 77:

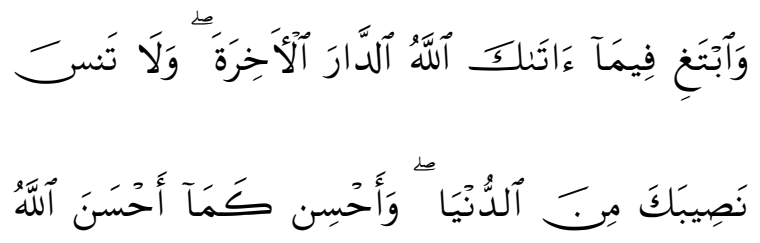

1) Jurnal ini merupakan bagian dari skripsi yang ditulis oleh, Rendra Akbar, NIM: 041114096, yang diuji pada 18 Mei 2015 


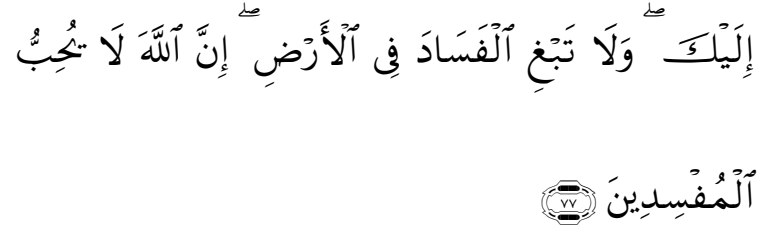

Artinya: "Dan carilah pada apa yang telah dianugerahkan Allah kepadamu (kebahagiaan) negeri akhirat, dan janganlah kamu melupakan bahagianmu dari (kenikmatan) duniawi dan berbuat baiklah (kepada orang lain) sebagaimana Allah telah berbuat baik, kepadamu, dan janganlah kamu berbuat kerusakan di (muka) bumi. Sesungguhnya Allah tidak menyukai orang-orang yang berbuat kerusakan."

Sebagai seorang muslim, tentu kita menginginkan investasi yang aman dan sesuai dengan aturan agama Islam. Salah satunya adalah dengan berinvestasi pada efek syariah yang terdaftar di BEl. Sejak November 2007, Bapepam LK telah mengeluarkan Daftar Efek Syariah (DES) yang berisi daftar saham Syariah yang ada di Indonesia. Keberadaan DES tersebut kemudian ditindaklanjuti oleh BEl dengan meluncurkan Indeks Saham Syariah Indonesia (ISSI) pada tanggal 12 Mei 2011. Konstituen ISSI terdiri dari seluruh saham Syariah yang tercatat di BEI. ( IDX, 2014 ).

Banyak sektor industri yang dapat dipilih untuk berinvestasi di pasar modal, diantaranya adalah sektor property dan real estate. Bisnis real estate dan property baik residensial maupun komersial menunjukkan perkembangan yang cukup pesat di Indonesia. Hingga kuartal II-2014, saham-saham sektor properti, real estate, dan konstruksi bangunan menjadi sektor yang paling banyak ditransaksikan. Hal ini tercermin dari data Bursa Efek Indonesia (BEI) yang menunjukkan, frekuensi perdagangan di sektor tersebut mencapai 4,81 juta kali. Total volume dari 54 saham yang diperdagangkan mencapai 152,7 juta saham. Adapun, nilai transaksi mencapai Rp 98,5 triliun (Hasniawati, 2014). Investor pasti mengharapkan adanya return yang akan diperoleh ketika melakukan investasi. Oleh karena itu, setiap investor akan melakukan analisis yang mendalam sebelum berinvestasi pada sebuah efek. Menurut Suardana dalam Magdalena ( 2011 : 22 ) return saham merupakan suatu variabel yang muncul dari perubahan harga saham sebagai akibat dari reaksi pasar karena adanya penyampaian informasi keuangan ( faktor fundamental) suatu entitas ke dalam pasar modal. Faktor fundamental dapat digunakan untuk memprediksi return saham adalah berupa analisis rasio, yaitu Rasio Aktifitas, Rasio profitabilitas, rasio hutang dan Rasio pasar.

Berdasarkan hal - hal tersebut diatas, penelitian ini bertujuan untuk dapat memberikan informasi kepada para investor mengenai pengaruh rasio pasar terhadap return saham yang akan diperoleh. Rasio pasar dipilih karena berkaitan langsung dengan tingkat pengembalian investasi. Serta rasio leverage yang dipakai hanya debt to equity ratio yang merupakan imbangan 
antara hutang yang dimiliki perusahaan dengan modal sendiri. Serta ISSI ( Indeks Saham Syariah Indonesia / digunakan sebagai obyek penelitian karena cakupan jumlah saham syariah yang terdaftar di dalamnya lebih banyak dan beragam dibanding dengan saham syariah yang terdaftar di JII.

Maka penelitian ini berusaha mencari tahu pengaruh rasio pasar seperti : Price earning Ratio ( PER ), Price Book Value (PBV ) dan Debt to Equity Ratio( DER) baik secara simultan maupun parsial terhadap return saham pada perusahaan property dan real estate yang terdaftar pada Indeks Saham Syariah Indonesia periode $2011-2013$

\section{LANDASAN TEORI}

Pada dasarnya tujuan utama dari seorang investor dalam berinvestsi adalah untuk mendapatkan return. Begitu juga bagi seseorang yang berinvestasi dalam saham, ia sudah pasti mengharapkan return saham. Secara sederhana return saham adalah hasil yang dinikmati oleh seorang investor dari investasinya pada saham. Ang dalam Widodo ( $2007: 23$ ) juga menyatakan hal yang serupa bahwa return saham itu adalah tingkat keuntungan yang dinikmati oleh pemodal atas suatu investasi saham yang dilakukannya.

Return saham dapat dihitung dengan persamaan berikut ( Ross et al. $2003: 238$ ) $: \mathrm{Rt}=\frac{P_{t}-P_{t-1}}{P_{t-1}}$
Keterangan :

$\mathrm{Pt}=$ harga investasi sekarang

$\mathrm{Pt}_{\mathrm{t}-1}=$ harga investasi periode lalu

Menurut Hartono(2009 : 145 ) PER (

Price Earning Ratio ) menunjukkan ratio dari harga saham terhadap earnings. Ratio ini menunjukkan berapa besar investor menilai harga dari saham terhadap kelipatan dari earnings.

Menurut Tandelilin ( $2010: 243$ ) rasio PER dapat diformulasikan sebagai berikUt : PER $=\frac{\text { Harga per lembar saham }}{\text { laba per lembar saham }}$

Price Book Value ( PBV ) merupakan rasio pasar ( market Rations) yang digunakan untuk mengukur kinerja harga pasar saham terhadap nilai bukunya ( Ang dalam Faried, 2008 : 32). PBV dapat dirumuskan sebagai berikut : PBV = $\frac{\text { Harga Pasar Saham }}{\text { Nilai Buku Per Lembar Saham }}$ ( Damodaran, $2012: 52$ ).

Harahap ( 1998 : 303 ) menyatakan bahwa DER mengambarkan sampai sejauh mana modal pemilik dapat menutupi hutang - hutang kepada pihak luar. Debt to Equity Ratio ( DER ) dapat dirumuskan sebagai berikut ( Damodaran, $2012: 52$ ) $:$ DER $=\frac{\text { Total Hutang }}{\text { Total Ekuitas }}$.

\section{METODOLOGI PENELITIAN}

Metode yang digunakan dalam penelitian ini adalah Regresi dengan menggunakan data panel disebut model regresi data panel. Ada beberapa keuntungan yang diperoleh dengan menggunakan data panel. Pertama, data 
panel yang merupakan gabungan dua data yaitu time series (selama beberapa tahun tertentu) dan cross section (pada beberapa perusahaan tertentu) yang mampu menyediakan data yang lebih banyak sehingga akan menghasilkan degree of freedom yang lebih besar (Gujarati, 2003:636). Kedua, menggabungkan informasi dari data time series dan cross section dapat mengatasi masalah yang timbul ketika ada masalah penghilangan variabel (omitted-variabel) (Widarjono, 2010:249). Untuk mengatasi interkorelasi diantara variabel-variabel bebas yang pada akhirnya dapat mengakibatkan tidak tepatnya penafsiran regresi, metode data panel lebih tepat digunakan (Hill dkk, 2001:351).

Populasi pada penelitian ini adalah perusahaan yang terdaftar dalam Bursa Efek Indonesia khususnya yang tergolong kedalam saham syariah yang tergabung dalam Indeks Saham Syariah Indonesia I ISSI ) pada tahun 2011 - 2013.

Sampel yang digunakan dalam penelitian in adalah emitien yang terdaftar dalam Indeks Saham Syariah Indonesia, dengan kriteria sebagai berikut :

1. Emiten terdaftar dalam Indeks Saham Syariah Indonesia pada periode $2011-2013$

2. Merupakan perusahaan properti dan real estate

3. Menerbitkan laporan keuangan pada tahun $2011-2013$

\section{Defenisi Operasional}

1. Return saham

Return saham atau pendapatan saham merupakan selisih dari harga saham pada penutupan akhir tahun tertentu dengan harga saham penutupan pada akhir tahu sebelumnya. Dan return saham dapat dihitung dengan rumus ( Ross et al. $2003: 238$ ) $:=\frac{P_{t}-P_{t-1}}{P_{t-1}}$

2. Price Earning Ratio ( PER )

Price Earning Ratio merupakan rasio antara harga saham dengan pendapatan setiap lembar saham. PER dihitung dengan menggunakan rumus Tandelilin ( 2010 : 243 ): Harga per lembar saham laba per lembar saham

3. Price Book Value (PBV)

Price Book Value merupakan rasio antara harga saham di pasar dengan nilai bukunya. PBV dihitung dengan rumus ( Damodaran, 2012 : 52 ) : $\frac{\text { Harga Pasar Saham }}{\text { Nilai Buku Per Lembar Saham }}$

4. Debt to Equity Ratio ( DER )

Debt to Equity Ratio merupakan ratio antara jumah hutang yang ada dengan modal sendiri. DER dihitung dengan rumus ( Damodaran, 2012:52 ) : $\frac{\text { Total Hutang }}{\text { Total Ekuitas }}$

\section{Jenis dan Sumber Data}

Bila dilihat dari sumber datanya, pengumpulan data dapat menggunakan sumber - sumber sekunder. Jenis data yang digunakan dalam penelitian ini 
adalah data sekunder. Menurut Siagian dan Sugiarto ( 2000 : 17 ) data sekunder merupakan data primer yang dieroleh oleh piha lain atau data yang telah diolah lebih lanjut dan disajikan oleh pengumpul data atau pihak lain yang umumnya berupa tabel atau diagram.

Data sekunder yang digunakan dalam penelitian ini berupa laporan keuangan yang didalamnya terdapat Price Earning Ratio, Price Book Value dan Debt to Equity Ratio tahunan perusahaan properti dan real estate yang terdaftar dalam Indeks Saham Syariah Indonesia periode 2011 - 2013. Data tersebut di ambil dari www.idx.co.id dan web lain yang berhubungan dengan laporan kevangan sampel.

\section{Teknik Pengumpulan Data}

Prosedur pengumpulan data dalam penelitian ii menggunakan beberapa cara, antar lain :

1. Studi Kepustakaan, bertujuan untuk mempelajari literatur - literatur, penelitian terdahulu, serta karya ilmiah yang digunakan untuk memahami permasalahan yang ada.

2. Mengumpulkan data sekunder yang dibutuhkan, berupa rasio - rasio yang terdapat dalam laporan keuangan, seperti Price Earning Ratio atau PER, Price Book Value atau PBV dan Debt to Equity Rasio atau DER

3. Data harga saham setiap enam bulan, dari data harga saham enam bulanan tersebut dihitung return saham setiap enam bulan sekali, setelah terkumpul dijumlah menjadi data per tahun kemudian dihitung dengan rumus yang telah ditentukan, yaitu mengetahui capital gain.

\section{Teknik Analisis Data}

Regresi dengan menggunakan data panel disebut model regresi data panel. Hal pertama yang harus dilakukan adalah Estimasi model regresi panel, terdapat 3 pendekatan yang biasa digunakan, yaitu CEM, FEM dan REM (Widarjono, 2010:251):

1. Common Effects Model (Pool least square)

Model common effects merupakan pendekatan data panel yang paling sederhana. Model ini tidak memperhatikan dimensi individu maupun waktu sehingga diasumsikan bahwa perilaku antar individu sama dalam berbagai kurun waktu. Model ini hanya mengkombinasikan data time series dan cross section dalam bentuk pool, mengestimasinya menggunakan pendekatan kuadrat terkecil/ pooled least square. Model ini di formulasikan sebagai berikut:

$Y_{i t}=\alpha+\beta_{1} X_{1 i t}+\beta_{2} X_{2 i t}+\beta_{3} X_{3 i t}+e_{i t}$ Keterangan:

$Y_{i t}$ : variabel dependen untuk individu ke-i dan waktu ke- $\dagger$

$X_{i t}$ : variabel independen untuk individu kei dan waktu ke- $\dagger$

2. Fixed Effects Model 
Model Fixed Effects mengasumsikan bahwa terdapat efek yang berbeda antar individu. Perbedaan itu dapat diakomodasi melalui perbedaan pada intersepnya. Teknik model fixed effect adalah teknik mengestimasi data panel dengan menggunakan variabel dummy untuk mengangkap adanya perbedaan intersep. Pengertian fixed effect ini didasarkan adanya perbedaan intersep antara perusahaan namun intersepnya sama antar waktu.

$Y_{i t}=\alpha+\beta^{\prime} x_{i t}^{\prime}+\sum_{i=2}^{n} \alpha_{i} D_{i}+u_{i t}$

Keterangan:

$D_{i}=$ Variabel Dummy

\section{Random Effects Model (Error Component Model)}

Model random effect ini menggunakan variabel gangguan (error terms). Model ini mengestimasi data panel dimana variabel gangguan mungkin saling berhubungan antar waktu dan antar individu. Model random effect dapat di formulasikan sebagai berikut:

$Y_{i t}=\alpha+\beta_{1} X_{1 i t}+\varepsilon_{i t} ; \varepsilon_{i t}=U_{i}+V_{t}+W_{i t}$

Keterangan:

$U_{i}:$ komponen error cross-section

$V_{t}:$ komponen error time-series

$W_{i t}:$ komponen error gabungan

Pemilihan Model Estimasi Regresi Data Panel

Menentukan estimasi model regresi panel, dilakukan beberapa uji untuk memilih metode pendekatan estimasi yang sesuai. Langkah-langkah yang dilakukan dalam mendapatkan model yang tepat adalah pertama dilakukan uji Chow pada hasil estimasi FEM, setelah terbukti ada efek individu maka dilakukan uji Hausman untuk menentukan antara FEM dan REM.

1. Chow Test (Uji Chow)

Uji Chow digunakan untuk memilih salah satu model pada regresi data panel, yaitu antara model efek tetap (fixed effect model) dengan model koefisien tetap (Common Effect Model). Dalam pengujian ini dilakukan hipotesa sebagai berikut :

$\mathrm{H}_{0}: \alpha_{1}=\alpha_{2}=\ldots=\alpha \mathrm{N}=\alpha$ (Model Common Effect)

$H_{1}$ : sekurang-kurangnya ada satu intersep $\alpha_{i}$ yang berbeda (Model Fixed Effect)

Dasar penolakan terhadap HO adalah dengan menggunakan F-statistik seperti berikut (Baltagi, 2005:15):

Chow $=\frac{R S S_{1}-R S S_{2} /(N-1)}{R S S_{2} /(N T-N-K)}$

dengan :

RSS1 = residual sum of square hasil pendugaan model common effect

RSS2 = residual sum of square hasil pendugaan model fixed effect

$\mathrm{N}=$ jumlah data cross section

$\mathrm{T}=$ jumlah data time series

$\mathrm{K}=$ jumlah variabel bebas

Statistik Chow Test mengikuti sebaran F-statistik yaitu $\mathrm{F}(\mathrm{N}-1, \mathrm{NT}-\mathrm{N}-\mathrm{K}) ; \alpha$. Jika nilai Chow statistik lebih besar dari F- 
tabel, maka menolak $\mathrm{H}_{0}$ dan sebaliknya. (Baltagi, 2005:15).

2. Hausman Test (Uji Hausman)

Uji hausman digunakan untuk membandingkan model Fixed Effect dengan Random effect. Uji hausman berdasar pada model fixed effect model yang mengandung suatu unsur trade off yaitu hilangnya unsur derajat bebas dengan memasukkan variabel dummy dan model Random Effect yang harus memperhatikan ketiadaan pelanggaran asumsi dari setiap komponen galat. Dalam pengujian ini dilakukan hipotesis sebagai berikut:

$\mathrm{H}_{0}: \operatorname{corr}\left(X_{i t}, U_{i t}\right)=0$ (Model Random Effect)

$\mathrm{H}_{1}: \operatorname{corr}\left(X_{i t}, U_{i t}\right) \neq 0$ (Model Fixed Effect)

Dasar penolakan HO dengan menggunakan Statistik Hausman dirumuskan sebagai berikut (Greene, 2000): $\chi^{2}(K)=(b-\beta)^{\prime}\left[\operatorname{Var}(b-\beta)^{-1}(b-\beta)\right.$

dengan:

$b=$ koefisien random effect

$\beta=$ koefisien fixed effect

Statistik hausman mengikuti sebaran Chi-Square, jika nilai $x 2$ hasil pengujian lebih besar dari $x 2(K, \alpha)(K=$ jumlah variabel bebas) atau P-Value $<\alpha$, maka dilakukan penolakan terhadap HO begitu pula sebaliknya.

\section{Uji Hipotesis}

1. Uji t-Statistik

Adalah sebuah uji yang digunakan untuk menguji pengaruh variabel bebas terhadap variabel terikat. Prosedur pengujiannya adalah:

a. Hipotesis statistik yang digunakan

$H_{0}: \mu=0$ berarti secara sendiri-sendiri (parsial) variabel bebas tidak ada pengaruh signifikan terhadap variabel terikat.

$H_{a}: \mu \neq 0$ berarti secara sendiri-sendiri (parsial) variabel bebas ada pengaruh signifikan terhadap variabel terikat.

b. Taraf kesalahan yang digunakanadalah $(\alpha)=5 \%$ dengan didasarkan pada $\mathrm{dk}=(\mathrm{n}-\mathrm{k}-1)$.

c. Harga t-hitung dapat dihitung dengan rumus:

$t_{\text {hitung }}: \frac{\text { Koefisien Determinasi (bi) }}{\text { Standard Deviasi (se(bi)) }}$

atau :

thitung $: \frac{(\mathrm{b} 1)}{(\mathrm{Sb} 1)}$

Keterangan:

bl = Parameter variabel eksogen

$\mathrm{Sbl}=$ Standar deviasi parameter variabel eksogen

Apabila thitung $>t_{\text {tabel }}$ atau nilai $\dagger$ yang dihasilkan pada tingkat signifikansi dibawah 0,05 (5\%), berarti pada pengujian ini tidak mampu atau gagal menerima $\mathrm{H}_{0}$ sehingga $\mathrm{H}_{\mathrm{a}}$ diterima. Demikian juga sebaliknya bila thitung < ttabel atau nilai t yang dihasilkan pada tingkat signifikansi diatas 0,05 (5\%), maka pengujian tidak mampu menolak $\mathrm{H}_{0}$ sehingga $\mathrm{H}_{0}$ diterima dan $\mathrm{H}_{\mathrm{a}}$ ditolak. 
2. Uji F-Statistik

Uji F dilakukan untuk mengetahui signifikansi pengaruh variable bebas terhadap variabel secara simultan, langkah yang diperlukan antara lain :

a. Perumusan Hipotesis

$H 0: \beta 1=\beta 2=\beta 3=0$, berarti variabel $X 1, X 2$ dan $X 3$ secara bersama-sama tidak berpengaruh secara signifikan terhadap variabel terikat.

$\mathrm{HO}: \beta 1 \neq \beta 2 \neq \beta 3 \neq 0$, berarti variabel $X 1, X_{2}$ dan $X 3$ secara bersama-sama berpengaruh secara signifikan terhadap variabel terikat.

b. Menentukan besarnya F hitung dengan rumus :

$$
F=\frac{R^{2} / k}{\left(1-R^{2}\right) /(n-k-1)}
$$

\section{c. Pengambilan Keputusan}

Jika Probabilitas $>0,05$ (level of significant $5 \%$ ) dan $\mathrm{F}$ hitung $<\mathrm{F}$ tabel (df $\mathrm{V} 1$ $=k$ dan $\mathrm{V} 2=n-k-1$ dan $a=5 \%$ ) maka $\mathrm{HO}$ diterima, sedangkan jika probabilitas $<0,05$ dan $\mathrm{F}$ hitung $>\mathrm{F}$ tabel maka $\mathrm{HO}$ ditolak.

3. $\quad$ Uji $R 2$ (R-square)

Pengujian ini dilakukan untuk mengukur seberapa besar persentase variabel dependen dapat dijelaskan oleh variabel independennya dengan melihat nilai $R 2$ (R-square) dari hasil estimasi. Nilai $R 2$ berkisar antara 0-1. Jika $R 2$ sama dengan 1, maka garis regresi yang digunakan mampu menjelaskan 100 persen variasi variabel dependen. Namun jika $R 2$ sama dengan 0 berarti variabel independen tidak dapat menjelaskan sedikitpun variasi variabel dependennya. Oleh karena itu, semakin tinggi $R 2$ maka variabel independen model akan semakin signifikan terhadap variabel dependennya.

\section{HASIL DAN PEMBAHASAN}

Penelitian ini menggunakan saham saham sayriah yang terdaftar di Indeks Saham Syariah Indonesia (ISSI) sebagai subjek penelitian. Sampel yang diambil adalah saham perusahaan properti dan real estate yang senantiasa terdaftar berturut - turut di ISSI pada tahun 2011 2013. Berikut daftar perusahaan properti dan real estate yang senantiasa terdaftar berturut - turut di ISSI pada tahun 2011 2013 yang bersumber dari www.idx.co.id.

Berdasarkan metode yang digunakan, maka langkah pertama adalah dengan melakukan uji chow serta uji Hausman untuk menentukan model mana yang paling cocok untuk digunakan pada penelitian ini.

\section{Uji Chow}

Uji Chow merupakan pengujian untuk melihat metode mana yang paling tepat digunakan antara CEM dan FEM. Pada dasarnya penentuan metode ini dilakukan dengan melihat ada atau tidaknya efek 
individu di dalam model, dengan hipotesis sebagai berikut:

$\mathrm{H}_{0}: \alpha_{1}=\alpha_{2}=\ldots=\alpha \mathrm{N}=\alpha$ (Model Common Effect)

$\mathrm{H}_{1}$ : sekurang-kurangnya ada satu intersep $\alpha_{i}$ yang berbeda (Model Fixed Effect)

Dari hasil perhitungan statistik dengan alat bantu berupa Eviews ver.07. diperoleh hasil output sebagai berikut:

Tabel 1

Output Eviews 7.0 Hasil Perhitungan Uji Chow

\begin{tabular}{|cccc|}
\hline Effects Test & Statistic & d.f. & Prob. \\
\hline \hline Cross- & & & \\
section F & 2.681971 & $(30,59)$ & 0.0006 \\
Cross- & & & \\
section Chi- & & & \\
square & 80.001768 & 30 & 0.0000 \\
\hline
\end{tabular}

Sumber : Hasil penelitian Data diolah (2015)

Berdasarkan tabel I, keputusan $\mathrm{H}_{0}$ ditolak jika $\mathrm{P}$-Value $<\alpha$ (0.05 atau 5\%). Berdasarkan output dari Eviews diperoleh P-Value ( Prob. Cross Section F) sebesar 0.0006. Karena P-Value $<\alpha$ yakni $0.0006<$ 0.05 maka diputuskan untuk menolak $\mathrm{H}_{0}$, artinya terdapat efek individidu pada model sehingga model yang sesuai adalah model FEM.

\section{Uji Hausman}

Berdasarkan hasil uji Chow di atas diketahui bahwa terdapat efek individu pada model. Selanjutnya dilakukan uji Hausman untuk menentukan metode mana yang paling tepat digunakan antara
Random Effect Models (REM) atau Fixed Effect Model (FEM) yang cocok dengan penelitian ini. Pemilihan model dilihat berdasarkan ada atau tidaknya korelasi antara komponen error cross-section dan variabel bebas dengan hipotesis sebagai berikut:

\begin{tabular}{|c|c|c|c|}
\hline \multicolumn{4}{|c|}{$\begin{array}{l}\text { Correlated Random Effects - Hausman Test } \\
\text { Equation: Untitled } \\
\text { Test cross-section random effects }\end{array}$} \\
\hline Test Summary & $\begin{array}{l}\text { Chi-Sq. } \\
\text { Statistic }\end{array}$ & Chi-Sq. d.f. & Prob. \\
\hline $\begin{array}{l}\text { Cross-section } \\
\text { random }\end{array}$ & 17.394227 & 3 & 0.0006 \\
\hline
\end{tabular}

$\mathrm{H}_{0}: \operatorname{corr}\left(X_{i t}, U_{i t}\right)=0$ (Model Random Effect)

$\mathrm{H}_{1}: \operatorname{corr}\left(X_{i t}, U_{i t}\right) \neq 0$ (Model Fixed Effect)

Dari hasil perhitungan statistik dengan alat bantu berupa Eviews ver.07. diperoleh hasil output sebagai berikut:

Tabel 2

Output Eviews 7.0 Hasil Perhitungan Uji Hausman

Sumber : Hasil penelitian Data diolah (2015)

Berdasarkan tabel 2, maka keputusan $\mathrm{H}_{0}$ ditolak jika $\mathrm{P}$-Value $<\alpha \quad 0.05$ atau 5\%). Berdasarkan output dari Eviews diperoleh P-Value ( Prob. Cross Section Random) sebesar 0.0006. Karena P-Value < $\alpha$ yakni $0.0006<0.05$ maka diputuskan untuk menolak $\mathrm{H}_{0}$, artinya tidak ada korelasi antara Xit dan $\varepsilon i$, sehingga metode estimasi yang sesuai adalah FEM. 
Berdasarkan Uji Chow dan Uji Hausman diperoleh kesimpulan bahwa model yang paling tepat untuk digunakan adalah model FIXED EFFECT MODEL (FEM).

\section{Uji Statistik}

Uji statistik yang dilakukan ada 2 :

a. Uji F-Statistik

Uji $F$ digunakan untuk menguji hipotesisis apakah secara bersama-sama variabel independen mempunyai pengaruh yang signifikan terhadap variabel dependen return saham para emiten Indeks Saham Syariah Indonesia (ISSI). Berikut hipotesis dan hasil statistik uji $\mathrm{F}$ sebagai berikut :

$H_{0}: \beta 1=\beta 2=\beta 3=0$, berarti variabel $X 1, X 2$ dan X3 secara bersama-sama tidak berpengaruh secara signifikan terhadap variabel terikat.

$H_{0}: \beta 1 \neq \beta 2 \neq \beta 3 \neq 0$, berarti variabel $X 1, X 2$ dan X3 secara bersama-sama berpengaruh secara signifikan terhadap variabel terikat.

Dalam memutuskan suatu hipotesis diterima atau tidak, ada ketentuan yang harus dipenuhi: $\mathrm{H}_{0}$ diterima bila: Fhitung < Ftabel atau nilai probability $>\operatorname{los}(\alpha) 5 \%$. $H_{0}$ ditolak bila: Fhitung $>$ Ftabel atau nilai probability $<\operatorname{los}(\alpha) 5 \%$.

Berikut ini adalah tabel uji $f$ menggunakan alat uji EViews 7.0 dengan nilai $F_{\text {tabel }}$ yakni $\mathrm{F} \alpha_{(\mathrm{k}, \mathrm{n}-\mathrm{k}-1}=\mathrm{F}_{0,05(3,89)}=2.7213$ serta interpretasi hasilnya.

Tabel 3
Output Eviews 7.0 Hasil Uji Statistik F

\begin{tabular}{|c|r|}
\hline F-hitung & 2.977801 \\
\hline Prob(F-statistic) & 0.000127 \\
\hline
\end{tabular}

Sumber : Hasil penelitian Data diolah (2015)

Berdasarkan Tabel diatas nilai Fhitung adalah 2.977801 lebih besar dari nilai Ftabel I yaitu 2,7213 dan nilai probability $F$ yang dihasilkan yakni 0,000127 yang kurang dari $\alpha=0,05$ (5\%), artinya pada pengujian ini dapat disimpulkan bahwa variabel PER, PBV, dan DER berpengaruh signifikan secara serentak terhadap return saham para emiten Indeks Saham Syariah Indonesia (ISSI).

b. Uji t-statistik

Uji † bertujuan untuk menganalisis tingkat signifikansi pengaruh variabel independen terhadap variabel dependen secara parsial. Untuk mengetahui apakah terdapat pengaruh secara parsial, sebelumnya maka dalam penelitian ini terdapat hipotesis statistik yang digunakan: $\mathrm{H}_{0}$ : berarti secara sendiri-sendiri (parsial) variabel independen berpengaruh tidak signifikan terhadap variabel dependen.

$\mathrm{H}_{\mathrm{a}}$ : berarti secara sendiri-sendiri (parsial) variabel independen berpengaruh signifikan terhadap variabel dependen.

Dalam memutuskan suatu hipotesis diterima atau tidak, ada ketentuan yang harus dipenuhi: $\mathrm{H}_{0}$ diterima bila: thitung $<t_{\text {tabel }}$ atau nilai probability $>\operatorname{los}(\alpha) 5 \%$. $H_{0}$ ditolak 
bila: thitung $>$ ttabel atau nilai probability $<$ los (a) $5 \%$.

Berikut ini adalah tabel uji $\dagger$ menggunakan alat uji EViews 7.0 dengan nilai tabel yakni $t_{a / 2(n-k)}=t_{0,025(90)}=1.98$ serta interpretasi hasilnya.

Tabel 4

Output Eviews 7.0 Hasil Estimasi Uji †

\begin{tabular}{||l|l|l|l|l|}
\hline Variabel & t-hitung & t-tabel & Prob & $(\alpha)$ \\
\hline PER & -4.158744 & 1.98 & 0.0001 & $5 \%$ \\
\hline PBV & 5.266155 & 1.98 & 0.0009 & $5 \%$ \\
\hline DER & -1.234495 & 1.98 & 0.2219 & $5 \%$ \\
\hline
\end{tabular}

Sumber : Hasil penelitian Data diolah (2015)

Tabel 5

Kesimpulan Uji- +

\begin{tabular}{|l|l|}
\hline Variabel & \multicolumn{1}{|c|}{ Keterangan } \\
\hline PER & $\begin{array}{l}\mid \text { thitung } \mid>t_{\text {tabel }}=\mathrm{H}_{0} \text { ditolak } \\
\text { nilai prob }<(\alpha)=\mathrm{H}_{0} \text { ditolak }\end{array}$ \\
\hline PBV & $\begin{array}{l}\mid \text { thitung } \mid>\text { tabel }_{\text {tab }}=\mathrm{H}_{0} \text { ditolak } \\
\text { nilai prob }<(\alpha)=\mathrm{H}_{0} \text { ditolak }\end{array}$ \\
\hline DER & $\begin{array}{l}\mid \text { thitung } \mid<\text { tabel }_{\text {tab }}=\mathrm{H}_{0} \text { diterima } \\
\text { nilai prob }>(\alpha)=\mathrm{H}_{0} \text { diterima }\end{array}$ \\
\hline
\end{tabular}

Sumber Hasil penelitian Data diolah (2015)

1. Variabel PER : $\mathrm{H}_{0}$ ditolak, dapat disimpulkan bahwa PER berpengaruh signifikan secara parsial terhadap return saham.

2. Variabel PBV: $\mathrm{H}_{0}$ ditolak, dapat disimpulkan bahwa PBV berpengaruh signifikan secara parsial terhadap return saham.
3. Variabel DER: $\mathrm{H}_{0}$ diterima, dapat disimpulkan bahwa DER berpengaruh tidak signifikan secara parsial terhadap return saham.

c. Uji 2 (R-square)

Tabel 6

Output Eviews 7.0 Hasil Estimasi Uji $R^{2}$

\begin{tabular}{|c|c|c|l|}
\hline$R$ & $R^{2}$ & $\begin{array}{c}\text { Adjusted } \\
R^{2}\end{array}$ & Interpretasi Hasil \\
\hline 0,376 & 0,624 & 0,415 & $\begin{array}{l}\text { Nilai R2 tersebut } \\
\text { mengindikasikan } \\
\text { bahwa variabel } \\
\text { bebas secara } \\
\text { simultan dapat } \\
\text { menjelaskan } \\
\text { variabel terikat } \\
\text { sebesar 62,4\% }\end{array}$ \\
\hline
\end{tabular}

Sumber : Hasil penelitian Data diolah (2015)

Pengujian ini dilakukan untuk mengukur seberapa besar persentase variabel dependen dapat dijelaskan oleh variabel independennya dengan melihat nilai $R 2$ (R-square) dari hasil estimasi. Model FEM memberikan nilai $R$-Squared sebesar $62.4843 \%$ seperti yang ditunjukkan output diatas. Artinya variabel independen dapat menjelaskan variabilitas dependen sebesar $62.4843 \%$ sedangkan sisanya $37.5157 \%$ dijelaskan oleh variabel lain yang belum masuk dalam model.

\section{Pembahasan}

Pembahasan hasil penelitian didasarkan pada uji F-statistik dan t-statistik untuk menguji apakah variabel PER, PBV dan DER 
memberikan pengaruh terhadap return saham dari perusahaan properti dan real estate yang terdaftar di Indeks Saham Syariah Indonesia (ISSI) periode 2011-2013.

Pengaruh Price Earning Ratio ( PER ) terhadap Return Saham

Dalam penelitian ini variabel PER memiliki nilai thitung sebesar -4.158744 dengan nilai probability sebesar 0.0001, maka dari hasil tersebut dapat disimpulkan bahwa nilai probability lebih kecil dari tingkat probability yang telah ditentukan yaitu 0.05. Sedangkan ttabel menunjukkan angka 1.98, maka | thitung | > tabel ( |4.158744|> 1.98). Hasil tersebut menunjukkan bahwa nilai PER berpengaruh signifikan terhadap return saham. Sedangkan koefisien PER bertanda negatif, berarti jika PER turun satu poin maka return saham akan naik dengan rasio 0.003 poin dan jika DER naik satu poin maka return saham akan tutun sebesar 0.003 .

Hasil diatas menunjukkan bahwa perubahan nilai Price Earning Ratio (PER) memberikan kontribusi negatif yang signifikan terhadap return saham syariah, yaitu kenaikan ataupun penurunan PER akan berdampak pada kenaikan atau penurunan return saham syariah secara bertolak belakang. Artinya, ketika PER mengalami kenaikan, return saham akan mengalami penurunan dan sebaliknya. Hal ini tidak sesuai dengan teori yang meyatakan bahwa perusahaan yang memiliki PER yang tinggi berarti memiliki return saham yang tinggi. PER suatu perusahaan yang relatif tinggi kemampuan menghasilkan labanya relatif rendah, karena investor akan membutuhkan waktu yang lama untuk mengembalikan modal.

PER yang relatif rendah menunjukkan bahwa laba per lembar sahamnya lebih tinggi dari harga sahamnya. Nilai laba per lembar saham yang tinggi mencerminkan profitabilitas yang baik yang berarti kinerja perusahaan semakin baik. Keuntungan yang dibagikan sebagai deviden akan lebih besar. Hal ini menjadi pertimbangan bagi investor untuk menanamkan modalnya di perusahaan tersebut.

Hasil penelitian ini sejalan dengan penelitian Meythi dan Mathilda ( 2012) yang menyatakan bahwa Price Earning Ratio (PER) berpengaruh negatif dan signifikan terhadap return saham. Tetapi, hasil dari penelitian ini bertentangan dengan penelitian Najmiyah dkk ( 2014 ) yang menyatakan bahwa Price Earning Ratio (PER) memiliki pengaruh positif dan signifikan terhadap return saham.

Hal ini menunjukkan bahwa selama periode penelitian, investor cendrung berinvestasi pada perusahaan yang memiliki PER yang rendah. Nilai PER yang rendah dapat menunjukkan bahwa perusahaan memiliki tingkat laba per saham yang tinggi jika dibandingkan dengan harga saham tersebut. Dapat disimpulkan bahwa pada periode ini investor tidak melihat harga saham sebagai acuan dalam berinvestasi, namun 
menggunakan tingkat laba per saham yang dihasilkan oleh perusahaan.

\section{Pengaruh Price Book Value ( PBV )} terhadap Return Saham

Dalam penelitian ini variabel PBV memiliki nilai thitung sebesar 5.266155 dengan nilai probability sebesar 0.0000, maka dari hasil tersebut dapat disimpulkan bahwa nilai probability lebih kecil dari tingkat probability yang telah ditentukan yaitu 0.05. Sedangkan ttabel menunjukkan angka 1.98, maka | thitung | > tabel | |5.266155 | > 1.98). Hasil tersebut menunjukkan bahwa nilai PBV berpengaruh signifikan terhadap return saham. Sedangkan koefisien PBV bertanda positif, berarti jika PBV naik satu poin maka return saham akan naik dengan rasio 0.97 poin dan jika PBV turun satu poin maka return saham akan tutun sebesar 0.97 .

Hasil diatas menunjukkan bahwa perubahan nilai Price Book Value (PBV) memberikan kontribusi positif yang signifikan terhadap return saham syariah, yaitu kenaikan ataupun penurunan PBV akan berdampak pada kenaikan atau penurunan return saham syariah secara searah. Artinya ketika PBV naik maka akan dikuti oleh kenaikan return saham dan ketika PBV mengalami penurunan maka return saham juga akan mengalami penurunan.

Signifikansi PBV menunjukkan bahwa investor menjadikan PBV sebagai salah satu faktor yang dilihat untuk melakukan investasi di pasar modal. PBV merupakan rasio pasar ( market rasio ) yang digunakan untuk mengukur kinerja harga pasar saham terhadap nilai bukunya. Semakin tinggi rasio PBV menunjukkan bahwa semakin berhasilnya perusahaan menciptakan nilai bagi pemegang saham. Semakin baik nilai perusahaan, maka investor akan semakin tertarik untuk menginvestasikan dananya. Dengan begitu harga saham akan naik dan return saham juga ikut naik.

Hasil penelitian ini sejalan dengan penelitian yang dilakukan oleh Nathaniel ( 2008 I yang menyatakan bahwa Price Book Value (PBV) berpengaruh positif dan signifikan terhadap return saham.

Dapat disimpulkan bahwa pada periode penelitian ini, investor menjadikan PBV sebagai salah satu alasan atau faktor untuk melakukan investasi di pasar modal. Hal ini terlihat dari signifikansi PBV serta nilai koefisiennya yang bernilai positif.

\section{Pegaruh Debt to Equity Ratio ( DER ) terhadap Return Saham}

Dalam penelitian ini variabel DER memiliki nilai thitung sebesar -1.234495 dengan nilai probability sebesar 0.2219, maka dari hasil tersebut dapat disimpulkan bahwa nilai probability lebih besar dari tingkat probability yang telah ditentukan yaitu 0.05. Sedangkan ttabel menunjukkan angka 1.98, maka | thitung $\mid<t_{\text {tabel }}(\mid$ $1.234495 \mid<$ 1.98). Hasil tersebut menunjukkan bahwa nilai DER berpengaruh tidak signifikan terhadap return saham. Sedangkan koefisien DER bertanda negatif, berarti jika DER turun satu poin maka return saham akan naik 
dengan rasio 0.69 poin dan jika DER naik satu poin maka return saham akan tutun sebesar 0.69 .

Hal ini sesuai dengan teori yang menyatakan bahwa tingkat DER yang relatif tinggi menunjukkan tingkat hutang yang tinggi, beban yang diderita perusahaan tinggi, hal ini dapat mengurangi laba perusahaan, deviden yang dibagikan juga semakin rendah. DER yang semakin kecil adalah semakin baik bagi posisi hutang perusahaan atau mengindikasikan perusahaan mampu melunasi hutang sesuai perjanjian, berarti kinerja manajemen dalam mengelola hutangnya baik. Rendahnya tingkat hutang baik untuk laba perusahaan krena beban yang dideriya perusahaan rendah, maka bagian laba yang dibagikan sebagai deviden pun meningkat, hal ini dapat menjadi daya tarik bagi investor lain untuk menanamkan modalnya pada perusahaan tersebut. Semakin tinggi permintaan akan suatu saham maka akan mendorong harga saham untuk bergerak naik. Selisih kenaikan harga saham tersebut juga dapat menjadi keuntungan bagi pemegang sahamnya.

Hasil penelitian ini sejalan dengan penelitian yang dilakukan oleh Rosartika ( 2006 ). Najmiyah dkk (2014) mengatakan bahwa Debt to Equity Ratio bepengaruh tidak signifikan terhadap return saham mungkin disebabkan oleh banyaknya variabel - variabel lain yang mempengaruhi return saham dan banyaknya faktor - faktor lain yang tidak dapat dikontrol seperti tingkat bunga, inflasi dan sebagainya yang berpengaruh.

Nathaniel ( 2008 ) mengatakan hal yang senada di dalam penelitiannya bahwa Debt to Equity Ratio (DER) berpengaruh negatif dan tidak signifikan terhadap return saham. Hasil penelitian ini menunjukkan bahwa informasi perubahan Debt to Equity ratio ( DER ) yang diperoleh dari laporan keuangan tidak berpengaruh pada keputusan atas harga saham di pasar modal Indonesia.

Pengaruh Price Earning Ratio ( PER ), Price Book Value ( PBV ) dan Debt to Equity Ratio ( DER ) terhadap Return Saham

Berdasarkan Tabel 4.9 nilai Fhitung adalah 2.977801 lebih besar dari nilai Ftabel yaitu 2,7213 dan nilai probability $F$ yang dihasilkan yakni 0,000127 yang kurang dari $\alpha=0,05(5 \%)$, artinya pada pengujian ini dapat disimpulkan bahwa variabel PER, PBV, dan DER berpengaruh signifikan secara serentak terhadap return saham perusahaan properti dan real estate yang terdaftar pada Indeks Saham Syariah Indonesia ( ISSI ) yang menjadi obyek penelitian tahun 2011-2013.

Hasil ini menunjukkan bahwa variabel independen yang terdiri dari PER, PBV dan DER relevan untuk dijadikan sebagai acuan dalam melakukan investasi di pasar modal. Khususnya untuk berinvestasi di saham syariah perusahaan properti dan real estate yang terdaftar di Indeks Saham Syariah Indonesia tahun 2011-2013. 


\section{SIMPULAN}

Berdasarkan pembahasan hasil penelitian yang telah dilakukan, maka simpulan yang dapat diambil dalam penelitian ini adalah

1. Variabel independen Price Earning Ratio ( PER ), Price Book Value ( PBV ) dan Debt to Equity Ratio ( DER ) secara parsial masing- masing memiliki pengaruh sebagai berikut :

a. Price Earning Ratio ( PER ) memberikan pengaruh negatif yang signifikan terhadap perubahan return saham syariah perusahaan properti dan real estate yang terdaftar di Indeks Saham Syariah Indonesia (ISSI I yang ditunjukkan dengan nilai thitung sebesar -4.158744 dengan tingkat signifikansi sebesar 0.0001 (dibawah $0.05)$.

b. Price Book Value ( PBV ) memberikan pengaruh positif yang signifikan terhadap perubahan return saham syariah perusahaan properti dan real estate yang terdaftar di Indeks Saham Syariah Indonesia ( ISSI ) yang ditunjukkan dengan nilai thitung sebesar 5.266155 dengan tingkat signifikansi sebesar 0.0000 (dibawah $0.05)$.

c. Debt to Equity Ratio ( DER ) memberikan pengaruh negatif yang tidak signifikan terhadap perubahan return saham syariah perusahaan properti dan real estate yang terdaftar di Indeks Saham Syariah
Indonesia ( ISSI ) yang ditunjukkan dengan nilai thitung sebesar -1.234495 dengan tingkat signifikansi sebesar 0.2219 ( diatas 0.05 ).

2. Variabel independen Price Earning Ratio ( PER ), Price Book Value ( PBV ) dan Debt to Equity Ratio ( DER ) secara simultan terbukti berpengaruh secara signifikan terhadap variabel dependen yaitu return saham syariah perusahaan properti dan real eatate yang terdaftar di Indeks Saham Syariah Indonesia (ISSI). Hal ini ditunjukkan oleh nilai Fhitung 2.977801 yang lebih besar dari nilai Ftabel yaitu 2,7213 dan nilai probability $F$ yang dihasilkan yakni 0,000127 yang kurang dari $a=0,05(5 \%)$.

\section{DAFTAR PUSTAKA}

Al - Quran Al- Karim. Terjemahan. Departemen Agama Indonesia

Anshori, Muslich \& Sri Isnawati. 2009. Metodologi Penelitian Kuantitatif. Cetakan Pertama. Surabaya : Pusat Penerbitan dan Percetakan UNAIR ( AUP )

Baltagi, B. H. ( 2005 ), " Economics Analysis of Data Panel" Third edition, Jhon Wiley \& sons Ltd. Chichester, England

Damodaran, Aswath. 2012. Investment Valuation. New Jersey : John Wiley \& Sons

Gujarati, Damodar (2003), Econometric, Erlangga, Jakarta.

Harahap, Shofyan Syafitri. 1998. Analisa Kritis Atas Laporan Keuangan. Edisi 
kesatu. Jakarta : PT.Rajasa Grafindo Persada

Hartono, Jogiyanto. 2009. Teori Portofolio dan Analisis Investasi. Edisi Keenam Yogyakarata: BPFE-Yogyakarta

Hasniawati, Amailia Putri. 2014. Saham Apa Yang Paling Sering Ditransaksikan? http://investasi.kontan.co.id/news/saha m-apa-yang-paling-sering-

ditransaksikan. Diakses pada 28 September 2014

Hidayat, Taufik. 2011. Buku Pintar Investasi Syariah. Jakarta : Media Kita

Hill, R.C., Grriffith, W.E dan Judge, G.G. 2001. Undergraduate Econometrics, $2^{\text {nd }}$ Edition, Jhon Wiley \& Sons, USA

IDX. 2010. Pasar Syariah. Diakses pada 13 Oktober 2014

Magdalena, Renn dan Josephine Kurniawati Tjahjono. 2011. Pengaruh Pasar terhadap Return Saham Perbankan di BEI Periode 2008-2010. Surabaya : Jurnal Akuntansi Universitas Pelita Harapan

Meythi dan Mariana Mathilda. 2012. Pengaruh Price Earning Ratio dan Price to Book Value terhadap Return Saham Indeks LQ 45 ( Periode 2007- 2009 ). Jurnal Akuntansi, Valume 4, Nomor 1, Mei 2012, hal. 1-21, ISSN : 2085-8698. Online.

http://repository.maranatha.edu/1945/1

/ diakses pada 10 oktober 2014)

Najmiyah, Edy Sujana dan $\mathrm{Ni}$ Kadek Sinarwati. 2014. Pengaruh Price to Book 1 PBV ), Price Earning Ratio( PER ) dan Debt to Equity Ratio ( DER ) terhadap
Return Saham Pada Industri Real Estate dan Property yang Terdaftar di Bursa Efek Indonesia Peride 2009 2013.Singaraja : e-Journal S1 Ak Univ Pendidikan Ganesha Jurusan Akuntansi Program S1 ( volume : 2 No. 1 Tahun 2014)

Nathaniel, Nicky. 2008. Analisis Faktor Faktor Yang Mempengaruhi Return Saham.Tesis tidak diterbitkan .Undip Semarang

Rosartika, Chrisnina. 2006. Pengaruh Debt to Equity Ratio, Price Earning Ratio, Price Book Value, dan Return on Assets terhadap Pendapatan Saham Pada perusahaan Mnufaktur yang Listing di Bursa Efek Jakarta. Skripsi UNAIR Surabaya

Ross, A Stephen. Westerfield, Randolph W. Jordan, Bradford D. 2003. Fundamentals of Corporate Finance. Sixth edition. New York : Mc Graw-Hill.

Siagian, Dirgibson dan Sugiarto. 2000. Metode Statistika Untuk Bisnis dan Ekonomi. Jakarta : PT Gramedia Pustaka Utama

Tandelilin, E. 2010. Portofolio dan Investasi Teori dan Aplikasi. Yogjakarta : Kanisius Widodo, Saniman. 2007. Analisis Pengaruh Rasio Aktivitas, Rasio Profitabilitas, dan Rasio Pasar, terhadap Return Saham Syariah Dalam Kelompok Jakarta Islamic Index ( JII ) Tahun 2003 - 2005. Tesis tidak diterbitkan. Univ. Diponegoro Semarang Widarjono, Agus. 2010. Analisis Statistika Mulivariat Terapan. Yogyakarta: UPP STIM YKPN 